\section{Medical therapeutic itineraries of women with breast cancer diagnosis affiliated to the People's Health Insurance in San Luis Potosí, central Mexico}

\author{
Itinerarios terapéuticos de mujeres con diagnóstico \\ de cáncer de mama afiliadas al Seguro Popular de \\ Salud en San Luis Potosí, región centro de México
}

\author{
Itinerários terapêuticos de mulheres com \\ diagnóstico de câncer de mama filiadas ao Seguro \\ de Saúde Popular em San Luís Potosí, região \\ central do México
}

\author{
1 Facultad de Enfermería, \\ Universidad Autónoma de \\ San Luis Potosí, San Luis \\ Potosí, México. \\ 2 Department of Public \\ Health Sciences, Karolinska \\ Institutet, Stockholm, \\ Sweden. \\ Correspondence \\ J. M. Espino \\ Department of Public \\ Health Sciences, Karolinska \\ Institutet. \\ Tomtebodavägen $18 \mathrm{~A}$, \\ Stockholm, SE-171 77, \\ Sweden. \\ joel.monarrez-espino@ki.se
}

\begin{abstract}
This study aims to describe the medical itineraries followed by breast cancer women affiliated to the People's Health Insurance in San Luis Potosí, central Mexico. We used an ethnographic approach based on oral histories of 12 women diagnosed with breast cancer in the year prior to the first meeting. Two face-to-face sessions per participant lasting 60 minutes each were conducted followed by a telephone interview. Content and diachronic analyses were used. Three main itineraries were identified: (1) diagnostic process, (2) final diagnosis to treatment, and (3) cancer control and relapse. Findings suggested that infrastructure and human resources to adequately screen and timely diagnose breast cancer were scant and insufficiently trained, respectively. Deferral of medical assessment was related with lack of information about breast cancer consequences, with women being afraid of a positive result, and with economic constraints. The current screening program needs to be redesigned to prevent diagnostic delays, as these seem to explain the high frequency of advanced stages reported at the time of diagnosis.
\end{abstract}

Breast Neoplasms; Health Services Accessibility; Qualitative Research
Luz María Tejada-Tayabas 1

Liseth Amell Salcedo 1 Joel Monárrez Espino 2

\section{Resumen}

Describir los itinerarios de atención medicalizada seguidos por mujeres con cáncer de mama, afiliadas al Seguro Popular de Salud en San Luis Potosí, México. Se realizó un estudio cualitativo con enfoque etnográfico en el que participaron 12 mujeres. Se recolectaron historias orales, dos entrevistas cara a cara y una telefónica por participante. Se efectuó análisis de contenido y diacrónico. Tres itinerarios fueron identificados en la búsqueda de atención: (1) el proceso de diagnóstico, (2) del diagnóstico al tratamiento, y (3) el control del cáncer y la recaída. Los hallazgos sugieren que la infraestructura y los recursos humanos son escasos para obtener una detección adecuada y un diagnóstico oportuno. El aplazamiento de la valoración médica también se relaciona con la falta de información sobre las consecuencias del cáncer y el temor de las mujeres al resultado. El programa de cribado actual necesita ser rediseñado para evitar retrasos de diagnóstico, los cuales parecen explicar la alta frecuencia de estadios avanzados reportados.

Neoplasias de la Mama; Accesibilidad a los Servicios de Salud; Investigación Cualitativa 


\section{Introduction}

Breast cancer is the most frequent malignancy among women worldwide with 1.38 million new cases diagnosed in 2008 (23\% of all cancers in women) 1. Since 2006, the breast cancer mortality rate has surpassed that of cervical cancer in Mexico, becoming the leading cause of death in women aged $\geq 25$ years, with a mean dying age of 59 years ${ }^{2}$. In 2011, the national mortality rate was 14/100,000 and San Luis Potosí was the third federal state with the highist rate reported among those aged $\geq 20$ years $(44.4 / 100,000) 3$. Breast cancer represents a major public health challenge for the Health Care System, not least financially, as nearly $60 \%$ of the cases are diagnosed in advanced stages 4,5 resulting in costs of around \$16,000 (US Dollars) per patient per year 6 .

At present, health services in Mexico are delivered by three main providers: social security institutions that cover nearly $40 \%$ of the population, private insurance companies covering roughly $10 \%$, and the remaining proportion, corresponding to the lower-income segment of the population, covered by the Ministry of Health through the People's Health Insurance established in $20044^{7}$. Actions to deal with this illness have included strengthening the specific breast cancer program through improvements in early detection, opportune treatment, and follow-up. Since 2007, breast cancer is covered by the Protection Fund against Catastrophic Expenditures within the System of Social Security in Health (i.e. People's Health Insurance) 7. Consequently, poor women with breast cancer receive comprehensive medical care in certified hospitals, including surgical procedures and follow-up, at no cost 8 . Unfortunately, current morbidity and mortality indicators have not yet reflected the actions undertaken; studies suggest that, in addition to factors associated with the health services' structure and organization that delay the timely detection and treatment 9,10, socioeconomic and cultural barriers can also be linked to the poor impact achieved 11,12.

Previous qualitative research on breast cancer has been useful to explore factors that affect the utilization of health services, including those investigating the women's perceptions about their role in deciding the appropriate treatment 13 , and their concerns and needs after receiving an abnormal mammogram 14. Qualitative researchers have also looked at reasons for the rejection of conventional medical treatment and the adoption of alternative medicine 15 , and others have studied experiences regarding discrimination in the provision of medical care 16 .
Therapeutic itineraries refer to the routes used to search, produce and manage health care and self-care; when used as an evaluation tool, they can reveal the strengths and weaknesses of health programs and services 17,18. Research on this field underscores the value of the therapeutic itineraries followed by patients and relatives in their pursuit for health care, including traditional and alternative medicine. So far, studies have focused on therapeutic itineraries dealing with acute 19,20,21 and chronic conditions 22,23,24. Therapeutic itineraries presuppose a sequence of decisions and negotiations among individuals and groups who have different perceptions and interpretations of diseases and the manner in which these should be dealt with. Understanding therapeutic itineraries followed by people seeking health care has been important to understand behavior in relation to health services' utilization 25 ; it helps identifying practical solutions to health problems and specific needs of those sick and their families considering the resources available.

Therefore, the current study aimed to describe the medical care itineraries followed by breast cancer women affiliated to the People's Health Insurance in San Luis Potosí, central Mexico.

\section{Participants and methods}

This study is part of a larger qualitative evaluation 26 of the breast cancer program in San Luis Potosí, Mexico. The design used here followed an ethnographic approach 27 . The study involved 12 newly diagnosed women or those with relapsing breast cancer within a year prior to the interview, affiliated to the People's Health Insurance, who were willing to participate, and who were registered in the support group "RETO", a non-governmental organization (NGO) that provides social assistance to women with breast cancer. This number of participants proved sufficient to achieve thematic saturation 28 in the context of therapeutic itineraries. Oral histories were recorded between January and July 2013, as this technique is useful to register a wide range of testimonies and experiences from a group of people about a specific topic 29 . A total of 36 interviews were conducted using an interview guide that covered topics related to the itineraries followed by women seeking care during each stage included in the breast cancer program, namely, detection, diagnosis, treatment, and follow-up, focusing on the times involved, the achievement of goals in each stage, and the barriers encountered (Table 1).

Two face-to-face sessions per participant lasting approximately one hour each were done 
Table 1

Thematic oral history interview guide.

\begin{tabular}{|c|c|}
\hline Topic & Themes \\
\hline \multirow[t]{7}{*}{ Detection } & How did you come to realize you had a lump in your breast? \\
\hline & What did you know about breast self-examination? \\
\hline & What did you think when you found something strange in your breast? \\
\hline & Where did you go when you found something in your breast? \\
\hline & How much time elapsed until you went for consultation? \\
\hline & What happened since the first consultation? What happened next? \\
\hline & What information and instructions did they give you? \\
\hline \multirow[t]{6}{*}{ Diagnosis } & Did you get additional studies? \\
\hline & How long after the first appointment did you get the mammography? \\
\hline & How long did it take to get the result of the mammography and who gave you the results? \\
\hline & Who performed the biopsy and where? How long after the mammography? \\
\hline & When and who gave you the results of the biopsy? \\
\hline & What did you do once you got the study results? (mammography, ultrasound, biopsy) \\
\hline \multirow[t]{5}{*}{ Treatment } & Please tell me what happened since you were notified that they had to operate and remove one or both breasts. \\
\hline & How much time elapsed form the final diagnosis to the mastectomy? \\
\hline & Could you please tell me about the chemotherapy? \\
\hline & If you received radiotherapy, could you please share your experience? \\
\hline & If you ever visited the emergency room in relation to the treatment, could you please share this experience? \\
\hline \multirow[t]{4}{*}{ Follow-up } & What recommendations and information did you receive at the end of the treatment? \\
\hline & What medical advice were you given for the follow-up of the disease? \\
\hline & Did you receive some kind of rehabilitation? \\
\hline & Tell me about your experience once the treatment was finished. \\
\hline
\end{tabular}

followed by a brief telephone interview to corroborate data and to obtain additional information when required.

The first interview to establish initial contact with the woman, to obtain baseline data, to build rapport with the informant, and to address the opening topics of the interview guideline, was conducted in the hospital at the time that the women visited for treatment by one of the authors (L.A.S) who participated as a volunteer for the RETO group. The second interview was done at either the household or the RETO group premises by two authors (L. A. S. and L. M. T.-T.) aimed at completing the in-depth interview. These two face-to-face interviews were audiotaped with the interviewees' consent and thereafter transcribed. Telephone interviews were recorded as field notes. Non-participant observations were used to understand the context in which health care is provided, including the women's households. Methodological and analytical field notes 30 were obtained during the whole data collection process.

Eight participants lived in the capital city of San Luis Potosí and four within the State limits.
Mean age was 43 years. Nine women were married, nine worked as housewives, and all had children. All had primary education, two had additional technical instruction, two had completed high school, and another two had college degrees. Eight were newly diagnosed patients, and four were relapsing with metastasis. All were considered poor, a prerequisite to be affiliated to the People's Health Insurance and to receive public health services (Table 2).

Data analyses relied on content 31 and diachronic 32 analyses to describe successful events in the search for medical care. Systematic codification and identification of themes using a chronological and inductive approach was used. All researchers participated in this process, which entailed the following steps: (1) systematic and literal transcription of the recorded interviews; (2) independent reading of transcriptions by researchers, and construction of initial codes to identify relevant themes; (3) pooling of all codes into a unique coding scheme; (4) second codification to identify narrative consistency and variability aimed at identifying therapeutic itineraries, including obstacles and advantages, and 
General characteristics of women participating.

\begin{tabular}{|c|c|c|c|c|c|c|c|c|}
\hline Informant & Age & Residence & Marital status & Children & Schooling & Occupation & Relapse & Comorbidity \\
\hline Leticia & 41 & Santa Teresa & Married & 5 & Primary & Housewife & No & No \\
\hline Lidia & 32 & San Luis Potosí & Married & 1 & High school & Secretary & No & No \\
\hline Sofia & 40 & El Jabalí & Married & 3 & Primary & Housewife & No & Diabetes \\
\hline Pilar & 32 & San Luis Potosí & Married & 2 & High school & Housewife & No & No \\
\hline Marina & 35 & San Luis Potosí & Married & 4 & Junior high & Housewife & Yes & No \\
\hline Irma & 50 & Villa Hidalgo & Married & 3 & Primary & Housewife & No & Diabetes \\
\hline Telma & 49 & Matehuala & Widow & 4 & High school & Merchant & No & No \\
\hline Carmen & 37 & San Luis Potosí & Married & 4 & High school & Hairdresser & No & Hypertension \\
\hline Isidra & 48 & San Luis Potosí & Single & 1 & High school & Housewife & Yes & No \\
\hline Cecilia & 59 & San Luis Potosí & Separated & 1 & College & Housewife & Yes & No \\
\hline Alejandra & 47 & San Luis Potosí & Married & 2 & College & Housewife & Yes & No \\
\hline Elisa & 44 & San Luis Potosí & Married & 3 & Primary & Housewife & No & Asthma \\
\hline
\end{tabular}

the timing involved; and (5) final discussion to establish consensus about the findings. The Atlas $\mathrm{Ti} /$ v.5.2 software 33 was used for the support of text interpretation. Finally, the results were verified ${ }^{34}$ by presenting these to the participants and to other women who corroborated the findings.

The study protocol was written in accordance to international ethical guidelines 35 , and approved by the Ethics Research Committee of San Luis Potosí Health Services. All participants provided verbal informed consent. Fictitious names were used in the quotes presented here.

\section{Results}

Four itineraries were identified from the women's narratives: The first related to the detection of the first sign of breast cancer and a visit to the physician including the use of diagnostic tests needed to confirm the diagnosis; the second involved actions and procedures linked to the oncological treatment provided and the clinical goals achieved according to the stage of breast cancer; the third itinerary dealt with the post-treatment stage, which included the follow-up period and the assessment of potential recurrences or metastasis; the last itinerary referred to the parallel route followed by patients aimed at illustrating the bureaucracy involved to access the People's Health Insurance, to obtain the corresponding benefits, and to seek support from NGOs.

\section{First itinerary: the diagnostic process}

According to participants, the time elapsed between initial detection and final diagnosis ranged from 3 to 18 months. At this stage, women made decisions regarding their choice of health services. Most mentioned that due to lengthy waiting times from previous experiences at public institutions they preferred to attend private sector health services expecting a quick and accurate diagnosis. All participants began the search for medical care right after or soon after accidentally detecting a "little lump" in one of their breasts, as they did not perform breast self-exam regularly. There were women who preferred to ignore the finding when detecting something unusual and postponed the medical revision. Irma mentioned that this can occur due to lack of knowledge about the potential consequences, and because some believe that nothing can happen at younger ages:

"I went to get it done [mammography] because I felt the lump, but I had felt it before, I just didn't think it could be something bad... I said, "why me?" I'm not that old... and also, I'd been operated from the womb, I didn't even have menses, and [it appeared] only in one breast" (Irma/50 years).

Half of the women mentioned that during the first assessment they were given a wrong diagnosis, such as supernumerary breast, abscess, cyst, and fibrocystic pathology. They were given either symptomatic treatment and/or antibiotics, and felt relieved for not having breast cancer. As a result they left the time pass until signs were overt and they had to seek medical care over again. This is how Carmen, who received medical care at a private clinic, explained it:

“...one day I found a small lump and went to see a doctor in a private clinic; they sent me to get an ultrasound, which I did, but [the person] who performed it said that it was 'nothing, just fibrocystic pathology'. I didn't know what that was. He told 
me to come back in a year for revision. I came back to the doctor when the lump was pretty large, and I had various lumps and a sunken nipple, the color changed, there was secretion once..." (Carmen/ 37 years).

For women, receiving a negative cancer diagnosis provides assurance, which often translated into an irrefutable trust in the equipment used for screening and diagnosis, and in the expertise and judgment of the medical personnel involved. This could prevent women from considering a second medical opinion. Instead, they waited the recommended 12-18 months before coming back for further revision, as Alejandra reported:

"If the physician tells you that there is nothing wrong, you believe it. One cannot think that he's wrong; deep inside you hope to be told that nothing is wrong... when the doctor told me if you want we can remove the lump, but it is not urgent, it is not necessary' I remained calm, and more so because we didn't have money. So, I didn't get the surgery, and left the time pass..." (Alejandra/ 47 years).

Seven women mentioned having been through various or repeated diagnostic procedures. While some had two mammograms or two biopsies, others went through different methods to establish the diagnosis (e.g. mammography, ultrasound, and biopsy), as the initial assessment was not confirmed. In other cases, patients did not receive the results due to technical errors or because considerable time had elapsed since the test was performed resulting in repeated exams. This is how Sofia described it:

"I visited two or three times the same doctor [public services]. He sent me to get a mammography in July. He told me it was okay. Then, there was a [health] campaign in November, wherer I got another one [mammography], but the result took two months, and it didn't specify all what I had" (Sofia/40 years).

The initiation of treatment was postponed in women who had diagnostic mistakes or delays leading to feelings of frustration for not having received appropriate care:

"It's frustrating that after one year they tell you that you have it [breast cancer]. Maybe if I was told what it was and what to do from the beginning we would have done it, and perhaps the situation would be different now; but anyway, there is no way back" (Alejandra/47 years).

\section{Second itinerary: from definitive diagnosis to treatment}

Once the diagnosis was definitive, the treatment course was more effective and expedited at the secondary level of care, especially for women in advanced stages who had taken a longer time to establish the final diagnosis. The time interval between the definitive diagnosis and the start of the treatment ranged from one to three months. Women were then referred for gynecological and oncological consultation to determine the treatment type and initiation date. The time elapsed between programing appointments with specialists and the actual consultation was short, including the carrying out of any additional tests. During this phase the waiting times were very much reduced. In spite of this, some women decided to get private care to prevent deferrals towards surgery and also expecting to receive better medical care even if this implied higher costs. Cecilia talked about it as follows:

"The doctor told me that a mastectomy and lymph node removal was needed. I told him 'yes, it's fine, health comes first'. We moved fast, everything in private care even though I was entitled to social security insurance, but I didn't feel confident getting health care there. I still had money saved from my retirement [pension], and with this I paid, and it was enough because the doctor told me that I didn't need chemotherapy, just the oral treatment" (Cecilia/59 years).

Various women faced difficulties in receiving chemotherapy, especially those from other cities that had to travel to San Luis Potosí as this implied time and money often resulting in missed appointments. Radiation therapy made it even more difficult and costly, as patients had to pay for a place to stay while attending daily session. Some reduced costs by traveling and staying alone (husbands usually stay working in their localities). Interviewees made it clear that the PHI did not cover indirect costs resulting from their illness:

“...I first came for chemotherapy to reduce the size of the tumor... after the surgery the doctor gave me revision appointments every Friday, but we ran out of money and I told my husband 'God, I wish I didn't have to come so often', but we had to come for radiations, and we had to find ways to pay what was needed..." (Telma/49 years).

The process required women to have laboratory tests (free with the People's Health Insurance) made prior to each chemotherapy session so that the oncologist could determine if the woman was fit to receive the treatment, which occurred every 3-4 weeks. This implied higher costs for those living in other localities that had to travel periodically. Some, like Telma, opted to pay for the tests in her hometown to avoid traveling with advance to the San Luis Potosí, as the travel expenses exceeded those of the tests.

"We pay exams [lab] that we have to bring here because it is more expensive if we come to get 
them done here. Just in transportation we spend 1.300 pesos [100\$] without meals, that's why we better get them done in Matehuala [200km away]" (Telma/49 years).

The treatment course was tough and lengthy, and more so for women traveling to San Luis Potosí to get chemotherapy. Waiting times at oncology services could be relatively long mainly due to the high demand. Bureaucratic procedures could also increase waiting times considerably. In order to receive one chemotherapy session, patients must stay in San Luis Potosí for an average of two days, including about eight hours of queuing time at the hospital if they have to get laboratory tests done and nearly 12 hours on the day of the session. This comprised getting the People's Health Insurance authorization, the consultation with the oncologist, and the procedure itself. Women faced having to line up while standing and fasting if blood samples were taken for lab analyses.

“...once I left very early, at least this is what I thought, to get the chemotherapy soon. It started at 9am, but it was already 9pm and it wasn't finished yet. I usually arrive at 7 am and leave between 7and 9pm" (Pilar/32 years).

For radiation therapy the waiting times were minimal. Each woman has a scheduled time, and the treatment authorization was made right away at the Radiotherapy Department. Most women spent less than an hour to receive this treatment. During or after chemotherapy some women developed side effects or aggravation of symptoms related to their clinical condition. Pilar mentioned that they often had to visit a private doctor or a pharmacy to get treatment when public services had fail to relieve their symptomatology.

"Every month when I was given the chemotherapy my defenses lowered and I got sick from my throat. I developed sores inside my mouth and I couldn't eat. I went to emergency care at the central hospital where they always gave me something that didn't help, and I continued with pain and fever. The last two occasions I didn't go [to the hospital] because it took hours. Once I was there from 10pm until 3am and said 'it's not worth it to spend so much time if I will go anyway to a private doctor" (Pilar/32 years).

\section{Third itinerary: cancer control, follow-up and relapse}

Some participants also described the procedures followed after completing the treatment. Basically, they had to visit the oncologist and have laboratory and radiology tests done monthly for the next three months. If they do not continue with antibody treatment, the visits will continue every 3-6 months for the next five years. In this phase the appointments are scheduled, thus the waiting times are reduced considerably.

No woman referred having received postoperative rehabilitation or information concerning the mobility of the affected extremity. In fact, public health services in San Luis Potosí lack specific rehabilitation programs to help these women recover their functional capacity. Irma was one of the patients who made reference to this topic:

"After the surgery the doctor told me to move the arm as little as possible, and with this instruction I left the hospital. I never asked when I would be able to move it [again]. I spent a month like that, with my arm attached, and it was very comfortable, but now I cannot move it, I can't do many things" (Irma/50 years).

Most participants mentioned that they never received psycho-emotional support to face the illness and its consequences. Two women reported contact with an undergraduate psychology student doing social service training at the hospital who offered support while receiving chemotherapy. Sofia actually decided to get support:

“...when I was in chemo, she [psychologist] started talking about who she was and what was she doing. I have been visiting her for two months. I tell her that I need professional support to deal with all the problems along with the disease, so many daily problems, economical and of all sorts; it does help talking to somebody" (Sofia/40 years).

Four women had breast cancer relapses. In such cases, one could identify similar itineraries with repeated tests, and diagnostic and treatment delays, as expressed by Marina:

"I was sent to get ultrasounds and $x$-rays. They told me 'cancer doesn't have word of honor and we cannot be confident', so I was under surveillance. But I never got things done in my head; they only looked at the liver and pancreas. Now, it turned out that I have the tumor on the right side of the head. I started in December with headache. I went here and there, from one doctor to the other, and they told me that it was migraine, but it was the cancer again" (Marina/35 years).

Although it is not part of the medical care, all participants mentioned having used traditional or alternative medicine to complement the conventional medical treatment. They mentioned that these treatments helped them better withstand the adverse effects of the chemotherapy, and to feel better in general. While only one woman replaced the medical treatment with an alternative therapy, many received advice from relatives, friends and others with cancer about complementary treatments for breast cancer, including homeopathy. Some women made refer- 
ence to the consumption of supplements with medicinal properties, ranging from capsules of "víbora de cascabel" (rattlesnake), and "cartílago de tiburon" (shark cartilage) to teas prepared with herbs such as the "uña de gato" (cat's nail), as Lidia recalled:

“During chemotherapy I was taking noni. It's a very good juice for some diseases. I have also taken 'florescence', which is already prepared. It helps me feeling better" (Lidia/32 years).

\section{Parallel itinerary: the People's Health} Insurance bureaucracy

Before starting the treatment, physicians often advised women to become affiliated to the people's health insurance to cope with the high costs resulting from the medical care, as Carmen recalled:

“...I got the biopsy done when the doctor told me that I had to receive care immediately. He asked me if I had people's health insurance. I said I didn't, and he told me 'activate your people's health insurance because it is possible that you get chemo and other things' so then I went to get the people's health insurance" (Carmen/37 years).

The affiliation to the people's health insurance and the program for catastrophic expenditures was simple and fast. However, the authorization process for each treatment session takes much more time due to the huge population demand for similar services.

“...I went to the people's health insurance, this didn't take much time, but every time one has to get the chemo or the lab you have to go and get the stamp and signature so that you don't have to pay, and this takes more and more time" (Cecilia/59 years).

For the women, getting the treatment costs covered was a major advantage. Most patients acknowledged the benefit represented in receiving the treatment and follow-up free of charge. Carmen asserted this in the following way:

“...I didn't have to pay for the chemo, thanks God, otherwise, I think I would be death; if I had to pay, I wouldn't have been able to take care of myself' (Carmen/37 years).

There seemed to be limited supply of various oral medications prescribed to some women who had to stop taking them unless they bought them at pharmacies, or until they were available in stock again.

“...there are other medications such as tamoxifen, aromasin [exemestane] and arimidex [anastrozole] that were prescribed to me after the chemotherapy, and that are covered by the people's health insurance provided that there are in stock, because sometimes they are not and one has to get them anyhow" (Carmen/37 years).

\section{Discussion}

This work describes medical care itineraries experienced by women diagnosed with breast cancer, which partially reflect some of the actions implemented by the Mexican Health System to provide appropriate care to affected women in the context of a rapidly increasing public health problem that demands effective actions for its control. At the same time, it reveals difficulties that women face from the detection and diagnosis to the treatment and follow-up stages.

Although it is fairly clear that the program for catastrophic expenditures and the treatment coverage for breast cancer constitute important assets of the health system, the infrastructure conditions and the human resources involved seem to be insufficient to provide opportune access and good quality care to breast cancer patients. This has been stated previously by other researchers who mentioned the need to ease the access of women to quality care by integrating and coordinating systematic actions at all levels of health provision 36 . Our findings add to the evidence that the resources required to adequately screen and diagnose women with breast cancer are still scant in terms of infrastructure and personnel - and possibly also insufficiently trained -, and point to the need to redesign the current screening program.

Results also revealed various delay mechanisms to establish the definitive breast cancer diagnosis that in part explain the high frequency of advanced stages reported at the time of diagnosis 36 . In some cases diagnostic delays were associated with ignorance and lack of information about the risks and consequences of breast cancer. Most of these women do not self-examine their breasts nor do they perform regular mammograms. Even among those who notice a lump, the deferral of medical assessment is common either because the woman is afraid of a positive result, or because of economic constraints to pay for the diagnostic procedures involved. Therefore, it is essential to raise consciousness among women about the relevance of regular check-ups, but also to inform financially deprived women about the possibility of receiving free medical care.

The excessive confidence in the physicians' diagnoses is more difficult to deal with. However, it is also important that women trust their doctor's instructions; while improving the training of medical personnel is essential, doctors should also develop communication skills to carefully explain to women about the sensitivity and specificity of the mammography and other diagnostic procedures. 
The failure to deliver diagnostic results in due time derives in increased costs and pointless confusion for the patient, family and treating physician. It is appalling that results can take up to 18 months to be delivered. To deal with this situation some patients opt to pay for private services to speed up the diagnostic process. However, those less privileged usually wait, which can lead to the detection of breast cancer in advanced stages. Diagnostic delays not only result in more complex and expensive treatment modalities, and in the reduction of survival chances and prognostic expectancy 11 , they also lead to additional emotional suffering and feelings of frustration and regret that must be avoided.

The troubles faced by breast cancer women in their quest for public health care portray a slow and relatively inefficient process. However, major structural issues need to be considered to better contextualize the findings observed. Many of the problems reported can only be solved by allocating a larger budget to expand the capacity of the clinical services, which currently cover only $24.7 \%$ of 14 million women aged $40-69$ year who constitute the target group for breast cancer 37 .

The fact that deprived women often seek additional private services could be rather paradoxical, as it is believed that quality of care is differential across socioeconomic strata in the population, whereby private care is less accessible to poor groups 9 . Authors have also reported that chronic patients of higher socioeconomic levels have increased access to private medicine ${ }^{38}$. Yet, for the participants of this study, the decision to use private services, referred in the first two health itineraries, was more associated with the delays and poor health care satisfaction with public services than with their financial possibilities.

This results in breast cancer patients and their families having to make exceptional sacrifices in order to afford the cost of private medicine in the hope of an opportune and accurate diagnosis.

The findings also reflect the importance given to costly curative actions, and highlight the little attention paid to the much cheaper primary prevention measures. More efforts in this direction are urgently needed in Mexico. Mass media campaigns and the use of new communication technologies (E-Health) can be of great help to promote self-breast examinations and to remind women about the importance of periodically carrying out mammograms 39,40 . On the other hand, breast cancer programs should also integrate the provision of psychological support and postsurgical physical rehabilitation 41,42 to improve the patients' quality of life, as it is done in other countries. The beneficial effect of counsel- ling and support groups for breast cancer women should be tailored to this disease as others have proposed 43,44,45.

The costs for poor women living in towns located far from the place where breast cancer treatment is available are noteworthy and exemplify a relevant barrier to access adequate care, as has been suggested elsewhere 46,47 , and call attention to the need to devise strategies to provide care to women living in these circumstances.

While the participants of this study neither represent the breast cancer population of San Luis Potosí state nor the city of San Luis Potosí, we believe that the findings presented here give voice to women sharing the breast cancer experience who follow similar routes in the quest to receive medical care. Given the lack of health care itineraries of cancer patients in Latin America, we think that our results provide relevant hints to advance the understanding of the problems faced by patients who live in comparable conditions in the region. Here, we have approached the topic in a country with a fragmented health system; whether similar problems are faced in settings with national health services remains to be explored, yet from the patients' perspective and not from that of the health authorities.

\section{Conclusion}

The intricate and lengthy therapeutic itineraries followed by breast cancer women in their quest for care make evident some of the shortcomings of the Mexican health system in terms of inadequate infrastructure and bureaucracy involved. These problems limit the full accomplishment of the goals set for each of the stages in the process of care resulting in reduced efficiency. The study also revealed the importance that the health system gives to expensive curative actions, contrasting with the poor attention given to cheap preventive and opportune diagnostic measures and with the almost forgotten strategies to improve post-treatment life quality (e.g. rehabilitation and psychological support measures).

The findings point to the need to redesign the current screening program. Delays to establish the definitive breast cancer diagnosis seem to explain the high frequency of advanced stages reported at the time of diagnosis in Mexico. 


\section{Resumo}

Descrever as rotas seguidas para os cuidados de mulheres com câncer de mama filiadas ao Seguro Popular de Saúde em San Luís Potosí, no México. Pesquisa qualitativa realizada com abordagem etnográfica, envolvendo 12 mulheres que foram diagnosticadas. Foram conduzidas histórias narradas por duas participantes, seguidas de uma entrevista por telefone. As análises do conteúdo e diacrônica foram realizadas. Três opções foram identificadas em busca de atenção: (1) o processo de diagnóstico, (2) a partir do diagnóstico até o tratamento, $e$ (3) controle e reincidência do câncer. Os resultados sugerem que os recursos de infraestrutura e humanos são escassos para a detecção adequada e diagnóstico oportuno. O adiamento da avaliação médica também está relacionado com a falta de informação sobre as consequências do câncer e o medo das mulheres em saber o resultado. O programa de rastreio atual precisa ser redesenhado para evitar atrasos no diagnóstico, que parecem explicar a alta frequência de estágios avançados relatados.

Neoplasias da Mama; Acesso aos Serviços de Saúde; Pesquisa Qualitativa

\section{Contributors}

L. M. Tejada-Tayabas conceptualized and designed the study, made substantial contributions to the data acquisition, analyzed and interpreted the data, drafted the first manuscript, and approved the final version to be published. L. Amell Salcedo made substantial contributions to the data acquisition analyzed and interpreted the data, and approved the final version to be published. J. Monárrez-Espino contributed to the data analyses and interpretation, participated in drafting and critically revising the manuscript for relevant intellectual content, and approved the final version to be published.

\section{References}

1. International Agency for Research on Cancer Breast cancer incidence and mortality worldwide in 2008. GLOBOCAN, 2008. Cancer fact sheet Lyon: IARC-WHO; 2010. http://globocan.iarc.fr/ factsheets/cancers/breast.asp (accessed on 17/ $\mathrm{Jul} / 2013$ ).

2. Martínez-Montañez OG, Uribe-Zúñiga P, Hernández-Avila M. Políticas públicas para la detección del cáncer de mama en México. Salud Pública Mex 2009; 51 Suppl 2:s350-60.
3. Instituto Nacional de Estadística y Geografía. Statistics on the international day against breast cancer. Aguascalientes: Instituto Nacional de Estadística y Geografía; 2013.

4. Villaseñor-Navarro Y. El cáncer de mama en México. Una tarea pendiente. Gac Mex Oncol 2012; 11:217-9.

5. Villaseñor-Navarro Y, Mohar-Betancourt A, OcejoMartínez A, Aguilar-Cortázar LO, Pérez-Badillo MP, Pérez-Sénchez VM, et al. Detección de cáncer de mama. Un compromiso con México (reporte preliminar). Gac Mex Oncol 2012; 11:220-7. 
6. Knaul F, Arreola-Ornelas H, Velázquez E, Dorantes J, Méndez O, Ávila-Burgos L. El costo de la atención médica del cáncer mamario: el caso del Instituto Mexicano del Seguro Social. Salud Pública Méx 2009; 51:286-95.

7. Gómez-Dantes O, Sesma S, Becerril VM, Knaul FM, Arreola H, Frenk J. Sistema de salud de México. Salud Pública Méx 2011; 53 Suppl 2:s220-32.

8. México. Reglamento interior de la comisión para definir tratamientos y medicamentos asociados a enfermedades que ocasionan gastos catastroficos. Diario Oficial de la Federación 2005; 12 sep.

9. Torres-Mejía G, Ortega-Olvera C, Ángeles-Llerenas A, Villalobos-Hernández AL, Salmerón-Castro J, Lazcano-Ponce E, et al. Patrones de utilización de programas de prevención y diagnóstico temprano de cáncer en la mujer. Salud Pública Méx 2013; 55 Suppl 2:s241-8.

10. Unger-Saldaña K, Infante-Castañeda C. Delay of medical care for symptomatic breast cancer: a literature review. Salud Pública Méx 2009; 51:270-85.

11. Nigenda-López G, González-Robledo LM, Caballero M, Zarco-Mera A, González-Robledo MC. Social process of breast cancer in Mexico. Perspective diagnosed women, their partners and providers of health services. México DF: Fundación Mexicana para la Salud; 2009.

12. Nigenda G, Caballero M, González-Robledo L. Barreras de acceso al diagnóstico temprano del cáncer de mama en el Distrito Federal y en Oaxaca. Salud Pública Méx 2009; 51 Suppl 2:s254-62.

13. O'Brien M, Charles C, Whelan T, Ellis P, Gafni A, Lovrics P. Women's perceptions of their involvement in treatment decision making for early stage breast cancer. Support Care Cancer 2013; 21: 1717-23.

14. Doré C, Gallagher F, Saintonge L, Hébert M. Breast cancer screening program: experiences of Canadian women and their unmet needs. Health Care Women Int 2013; 34:34-49.

15. Citrin DL, Bloom DL, Grutsch JF, Mortensen SJ, Lis CG. Beliefs and perceptions of women with newly diagnosed breast cancer who refused conventional treatment in favor of alternative therapies. Oncologist 2012; 17:607-12.

16. Quach T, Nuru-Jeter A, Morris P, Allen L, Shema SJ, Winters JK, et al. Experiences and perceptions of medical discrimination among a multiethnic sample of breast cancer patients in the Greater San Francisco Bay Area, California. Am J Public Health 2012; 102:1027-34.

17. Bellato R, Araújo LFS, Castro P. O itinerário terapêutico como uma tecnologia avaliativa da integralidade em saúde. In: Pinheiro R, Silva AG, Mattos RA, organizadores. Atenção básica e integralidade: contribuições para estudos de práticas avaliativas em saúde. Rio de Janeiro: Instituto de Medicina Social, Universidade do Estado do Rio de Janeiro/ABRASCO; 2008. p. 167-87.
18. Gomes FR, Bonet O. Itinerário terapêutico e práticas avaliativas: algumas considerações. In: Pinheiro R, Silva AG, Mattos RA, organizadores. Atenção básica e integralidade: contribuições para estudos de práticas avaliativas em saúde. Rio de Janeiro: Instituto de Medicina Social, Universidade do Estado do Rio de Janeiro/ABRASCO; 2008; p. 189-96.

19. Nabão F, Maruyama SA. The experience of illness and the therapeutical itinerary experienced by a person with infarction. Rev Eletrônica Enferm 2009; 11:101-9.

20. Lago LM, Martins JJ, Schneider DG, Barra DCC, Nascimento ERP, Albuquerque GL, et al. Itinerario terapéutico de los usuarios de una urgencia hospitalar. Ciênc Saúde Coletiva 2010; 15 Suppl 1: s1283-91.

21. Oliveira BR, Collet N, Mello DF, Lima RA. The therapeutic journey of families of children with respiratory diseases in the public health service. Rev Latinoam Enferm 2012; 20:453-61.

22. Ribeiro MG, Santos SM, Teixeira MT. Therapeutic itinerary of women with cervical neoplasms: an approach focused on prevention. Rev Bras Cancerol 2011; 7:483-91.

23. Fundato C, Petrilli AS, Dias C, Gutiérrez MGR. Therapeutic itinerary of teenagers and young adults with osteossarcoma. Rev Bras Cancerol 2012; 58:197-208.

24. Bellato R, Araújo LFS, Faria APS, Costa ALRRC, Maruyama SAT. Itinerários terapêuticos de famílias e redes para o cuidado na condição crônica: alguns pressupostos. In: Pinheiro R, Martins PH, organizadores. Avaliação em saúde na perspectiva do usuário: abordagem multicêntrica. Rio de Janeiro: Editora CEPESC; 2009. p. 187-94.

25. Cabral AL, Martinez-Hemáez A, Andrade EI, Cherchiglia ML. Itinerários terapêuticos: o estado da arte da produção científica no Brasil. Ciênc Saúde Coletiva 2011; 16:4433-42.

26. Tejada-Tayabas LM. Theoretical, conceptual and practical challenges of qualitative assessment in health in Latin America. In: Mercado FJ, Mercado A, editors. Emerging evaluation of health policies and programs: progress and challenges in Latin America. Mérida: Universidad Autónoma de Yucatán/Consorcio de Universidades Mexicanas; 2010. p. 79-106.

27. Cook K. Using critical ethnography to explore issues in Health Promotion. Qual Health Res 2005; 15:129-38.

28. Guest G, Bruce A, Johnson L. How many interviews are enough? An experiment with data saturation and variability. Field Methods 2006; 18:59-82.

29. Aceves-Lozano JE. Oral history, biographic memory, and communication: from descriptive to analytic reflexive writing. Oral History Forum 2012; (32). 
30. Emerson RM, Fretz RI, Shaw LL. Writing ethnographic fieldnotes. Chicago: University of Chicago Press; 1995.

31. Hsieh HF, Shannon SE. Three approaches to qualitative content analysis. Qual Health Res 2005; 15:1277-88.

32. Stables A. Diachronic and synchronic analysis of educational practice: taking account of the life history. Int J Res Meth Educ 2002; 25:59-66.

33. Muhr T. ATLAS/Ti-A prototype for the support of text interpretation. Qual Sociol 1991; 14:349-71.

34. Silverman D. Doing qualitative research. Thousand Oaks: Sage Publications; 2003.

35. Murphy E, Dingwall R. The ethics of ethnography. In: Atkinson P, Coffey A, Delamont J, Hofland LH, editors. Handbook of ethnography. London: Sage Publications; 2001. p. 339-51.

36. González-Robledo LM, González-Robledo MC, Nigenda G, López-Carrillo L. Acciones gubernamentales para la detección temprana del cáncer de mama en América Latina. Retos a futuro. Salud Pública Méx 2010; 52:533-43.

37. Reynoso-Noverón N, Villaseñor-Navarro Y, Hernández-Ávila M, Mohar-Betancourt A. Carcinoma in situ e infiltrante identificado por tamizaje mamográfico oportunista en mujeres asintomáticas de la Ciudad de México. Salud Pública Méx 2013; 55:469-77.

38. Becker G, Newsom E. Socioeconomic status and dissatisfaction with health care among chronically ill African Americans. Am J Public Health 2003; 93:742-8.

39. Kratzke C, Wilson S, Vilchis H. Reaching rural women: breast cancer prevention information seeking behaviors and interest in internet, cell phone and text use. J Community Health 2013; 38:54-61.
40. Woloshin S, Schwartz LM, Black WC, Kramer BS Cancer screening campaigns getting past uninformative persuasion. N Engl J Med 2012; 367:1677-9.

41. Binkley JM, Harris SR, Levangie PK, Pearl M, Guglielmino J, Kraus V, et al. Patient perspectives on breast cancer treatment side effects and the prospective surveillance model for physical rehabilitation for women with breast cancer. Cancer 2012; 118(8 Suppl):2207-16.

42. Schmitz KH, Stout NL, Andrews K, Binkley JM, Smith RA. Prospective evaluation of physical rehabilitation needs in breast cancer survivors. Cancer 2012; 118(8 Suppl):2187-90.

43. Marshall CA, Badger TA, Curran MA, Koerner SS, Larkey LK, Weihs KL, et al. Un abrazo para la familia: providing low-income hispanics with education and skills in coping with breast cancer and caregiving. Psychooncology 2013; 22:470-4.

44. Mallinckrodt B, Armer JM, Heppner PP. A threshold model of social support, adjustment, and distress after breast cancer treatment. J Couns Psychol 2012; 59:150-60.

45. Cozaru GC, Papari AC, Sandu ML. The effects of psycho-education and counselling for women suffering from breast cancer in support groups. Procedia - Social and Behavioral Sciences 2014; 128:10-5.

46. Stanley S, Arriola KJ, Smith S, Hurlbert M, Ricci C, Escoffery C. Reducing barriers to breast cancer care through a patient navigation programs. J Public Health Manag Pract 2013; 19:461-7.

47. Primeau W, Freund KM, Ramachandran A, Bak SM, Heeren T, Chen CA, et al. Social service barriers delay care among women with abnormal cancer screening. J Gen Intern Med 2014; 29:169-75.

Submitted on 21/Jan/2014

Final version resubmitted on 18/Jul/2014

Approved on 29/Aug/2014 